\title{
Haemato-Biochemical Alterations in Pyometra Affected Bitch
}

\author{
S. P. Maharathi ${ }^{1}$, N. Dalai ${ }^{1 *}$, S. Mohapatra ${ }^{1}$, S. R. Mishra ${ }^{1}$, \\ A. P. K. Mahapatra', A. K. Kundu' ${ }^{1}$, I. Nath ${ }^{2}$ and S. Dash ${ }^{3}$ \\ ${ }^{1}$ Department of veterinary Physiology, ${ }^{2}$ Department of Surgery and radiology, \\ ${ }^{3}$ Department of Animal Breeding and Genetics, \\ College of veterinary science \& A.H, OUAT, Bhubaneswar-751003, Odisha, India \\ *Corresponding author
}

\section{A B S T R A C T}

Keywords

Biochemical,

Globulin,

Haematological,

Pyometra, PCV

\section{Article Info}

Accepted:

18 May 2020

Available Online:

10 June 2020
In the present study an attempt was made to evaluate haematological as well as biochemical changes in pyometra affected bitches and was compared with control group. A total of 20 bitches of age group 6-10 years old irrespective of breed were clinically examined and diagnosed for pyometra. Evaluation of haematological changes revealed that there was decreased PCV, Hb, TEC, lymphocytes and monocytes values were significantly $(\mathrm{P}<0.05)$ low whereas TLC \& neutrophil significantly ( $\mathrm{P}$ $<0.05)$ higher in pyometra affected bitches than control. Further biochemical studies showed significant increase $(P<0.05)$ in concentration of serum glucose, cholesterol, total protein, globulin in affected bitches There were no significant differences of serum albumin concentrations in both the groups.

\section{Introduction}

Pyometra is the chronic subacute metritis or endometritis which is common in intact bitches of all age groups but mostly seen over 6 years of age (Jitpean, et al., 2014). Pyometra in bitches usually occur in a diestrous phase of estrous cycle and is defined as the hormonally medicated diestrual reproductive disorders (Smith, 2006). It is bacterial infection of the uterus in intact, sexually mature bitches, culminate to accumulation of purulent material in the uterine horn (Prasad, et al., 2017).

Progesterone has been shown to stimulate endometrial glandular secretion followed by suppress contractions of the uterus, thus creating an intrauterine environment make susceptible to bacterial growth. Moreover nulliparous bitches are highly prone for pyometra (Smith, 2006). (Hagman, et al., 
2009; and Dabhi and Dhami, 2007) reported that haematobiochemical alteration is indication of leucocytosis. Therefore the objective of present study was to demonstrate haematological and biochemical changes in pyometra affected bitches which are considered significant to evaluate the severity and type of case.

\section{Materials and Methods}

This study was carried out in Teaching Veterinary Clinical complex of college of Veterinary Science \& Animal Husbandry, OUAT, Bhubaneswar from the month of April to May, 2017. Haemato-biochemical parameters were analysed on 20 female dogs with age ranging from 6-10 years old irrespective of breed affected and was compared with 15 of same age group. The confirmatory diagnosis of open pyometra was based on case history, clinical signs (mucopurulent vaginal discharge, enlarged abdomen, fever, polyurea etc). $3 \mathrm{ml}$ of blood was collected with aseptic precautions from the radial vein using EDTA vials for haematological study and for serum, $5 \mathrm{ml}$ of blood was collected without any anticoagulants.

During collection of blood samples from bitches attention had been paid to minimize pain and all the samples collection were carried out in accordance with the guidelines laid down by the International Animal Ethics Committee. Haematological parameters like $\mathrm{Hb}, \mathrm{PCV}$, TLC and TEC, Differential leukocyte count (neutrophil, eosinophil, lymphocyte and monocyte count) were estimated as per the standard protocol. Biochemical parameters like glucose, cholesterol, Total protein, albumin and globulin were estimated by Clinical analyzer (Systronic 635). Standard commercial kits were used for analysis and procedures were adopted as recommended by the manufacturer of kits (Coral Clinical Systems). Globulin concentration in serum was determined by subtracting albumin from total protein.

The data were subjected to the statistical analysis using SPSS. One-way ANOVA and least significant differences (LSD) post hoc tests were performed to assess significant differences among means where $\mathrm{P}<0.05$ was considered statistically significant.

\section{Results and Discussion}

Haematological and biochemical parameters were compared between pyometra affected bitches and control group and the values were depicted in Table 1. Haematological study revealed $\mathrm{Hb}, \mathrm{PCV}$ and TEC values were significantly $(\mathrm{P}<0.05)$ lower in affected group as comparedto control. Higher value of TLC count was observed in pyometra affected group. There was a significantly $(\mathrm{p}<0.05)$ higher value of neutrophil, and lower percentage of lymphocytes, monocytes in affected group. Biochemical parameters revealed that there was significant increase $(\mathrm{P}$ $<0.05)$ in concentration of glucose, cholesterol, total protein and globulin in pyometra affected bitches as compared to control groups. However no significant difference in the serum value of albumin in between control and affected group was observed.

The study revealed significant $(\mathrm{P}<0.05)$ low $\mathrm{PCV}$ value in affected bitches as compared to control, indicating regenerative type of anaemia. The same was reported earlier (Jena, et al., 2013; Dabhi, et al., 2009). Low Hb value indicated mild anaemia in this case which is due to decreased erythropoiesis and loss of erythrocytes into uterine lumen (Nath, et al., 2009). The anemia in affected dogs can be attributed to toxic depression of bone marrow and due to loss of red cells into the uterine lumen. 
There was significant $(\mathrm{P}<0.05)$ low value of TEC count in comparison to control group which was in agreement with the findings of (Nath. K. et al., 2009) who suggested that reduced erythropoiesis leads to decreased TEC.

TLC in this present study showed significant $(\mathrm{P}<0.05)$ higher value than the control group, reflecting the higher amount of inflammatory response initiated by the disease and due to diffused suppurative inflammation of uterus to combat the infection as suggested earlier (Nath, et al., 2009).

There was a significant $(\mathrm{p}<0.05)$ high value of neutrophil than the control group value, which might be due to bacterial growth as uterine glandular secretion provides excellent media for growth of them (Jena, B. et al., 2013). Percentage of lymphocytes \& monocytes showed significantly $(\mathrm{P}<0.05)$ lower values than the control group. The present findings are in accordance with (Faldyna, et al., 2001) who suggested that it may be due to immunosuppression associated with pyometra. In biochemical study, hypercholesterolemia was observed due to bacterial infection which agreed with the finding of (Shyma, and Vijayakumar, 2011). The observed hyperproteinemia in this present study is in agreement with the finding of (Gupta, et al., 2013). Hyperproteinemia in these cases might be due to acute phase reaction in pyometra affected bitches (Singh, et al., 2006).

The Hyper-globulinemia, concurrent with hypoalbuminemia in this present study was in agreement with (Singh, S. et al., 2006; Reidun, H. et al., 2007)who suggested that it is due to chronic inflammation with compensatory decrease in albumin production as there might be loss of albumin in urine. The synthesis of antibodies in response to bacterial infection as mentioned by (Hagman, $\mathrm{R}$, 2004) is also a contributing factor for hyper-globulinemia.

Table.1 Haemato-biochemical changes in pyometra affected group

\begin{tabular}{|l|l|c|c|}
\hline Sl.No & $\begin{array}{l}\text { Haemato-Biochemical } \\
\text { Parameters }\end{array}$ & $\begin{array}{c}\text { Control } \\
\text { Group }(\mathbf{N}=\mathbf{1 5})\end{array}$ & $\begin{array}{c}\text { Affected Group } \\
(\mathbf{N}=\mathbf{2 0})\end{array}$ \\
\hline 1. & PCV $(\%)$ & $39.41^{\mathrm{a}} \pm 1.34$ & $29.73^{\mathrm{b}} \pm 1.17$ \\
\hline 2. & Hb $(\mathrm{g} / \mathrm{dl})$ & $14.01^{\mathrm{a}} \pm 0.51$ & $9.36^{\mathrm{b}} \pm 0.62$ \\
\hline 3. & TLC $\left(10^{3} / \mu \mathrm{l}\right)$ & $12.16^{\mathrm{a}} \pm 1.10$ & $77.35^{\mathrm{b}} \pm 0.66$ \\
\hline $\mathbf{4 .}$ & TEC $\left(10^{6} / \mu \mathrm{l}\right)$ & $6.95^{\mathrm{a}} \pm 0.55$ & $5.10^{\mathrm{b}} \pm 0.34$ \\
\hline $\mathbf{5 .}$ & Neutrophils $(\%)$ & $66.83^{\mathrm{a}} \pm 1.30$ & $84.5^{\mathrm{b}} \pm 1.56$ \\
\hline 6. & Lymphocytes $(\%)$ & $19.83^{\mathrm{a}} \pm 1.03$ & $13.83^{\mathrm{b}} \pm 1.21$ \\
\hline 7. & Monocytes $(\%)$ & $3.5^{\mathrm{a}} \pm 0.37$ & $1.33^{\mathrm{b}} \pm 0.23$ \\
\hline 8. & Eosinophils $(\%)$ & $1.83 \pm 0.33$ & $0.66 \pm 0.24$ \\
\hline 9. & Glucose $(\mathrm{mg} / \mathrm{dl})$ & $82.5^{\mathrm{a}} \pm 2.90$ & $93.83^{\mathrm{b}} \pm 4.11$ \\
\hline $\mathbf{1 0 .}$ & Cholesterol $(\mathrm{mg} / \mathrm{dl})$ & $84.66^{\mathrm{a}} \pm 1.46$ & $237.16^{\mathrm{b}} \pm 4.69$ \\
\hline 11. & Total Protein $(\mathrm{g} / \mathrm{dl})$ & $6.61^{\mathrm{a}} \pm 0.22$ & $8.33^{\mathrm{b}} \pm 0.30$ \\
\hline 12. & Albumin $(\mathrm{g} / \mathrm{dl})$ & $3.08 \pm 0.19$ & $2.52 \pm 0.42$ \\
\hline 13. & Globulin $(\mathrm{g} / \mathrm{dl})$ & $3.53^{\mathrm{a}} \pm 0.17$ & $5.81^{\mathrm{b}} \pm 0.31$ \\
\hline
\end{tabular}

Superscript bearing different letters $(a, b)$ in the same row differ significantly $(\mathrm{P}<0.05)$ ( $\mathrm{N}$ in Table-1 indicates number of animal) 
Haematological parameters showed neutrophilia, leukocytosis, lymphocytopenia, anemia whereas biochemically elevated profiles of cholesterol, total protein with hypoalbuminemia and hyperglobunemia observed in pyometra affected bitches as compared to heathy ones.

\section{References}

Dabhi, D.M. and Dhami A.J., 2007. Studies on clinico-epidemiology and surgical management of canine pyometra. Indian J. Field Vets, 2: 11-18.

Dabhi, D.M., Dhami, A.J., Parikh, P.V. and Patil, D.B. 2009. Comparative evaluation of haematological parameters in healthy and pyometra affected bitches. Indian Journal of Animal Reproduction, 30(1): 70-72.

Faldyna, M., Laznicka, A. and Tomas, M. 2001. Immunosuppression in bitches with pyometra.J Small AnimPract, 42(1): 5-10.

Gupta, A.K. and Dhami, A.J. 2013. Haematological changes inbitches affected with pyometra. The Ind J Vet Scs and biotech, 9: 123-129.

Hagman, R. 2004. New aspects of canine pyometra. Studies on epidemiology and pathogenesis. Doctoral thesis, Swedish University of Agril Sci., Uppsala, Sweden.

Hagman, R., Reezigt, B.J., Ledin, H.B. and Karlstam, E. 2009. Blood lactate levels in 31 female dogs with pyometra. Europ. Compan. Ani. Health, 1(1): 1-8.

Jena, B., Rao, K.S., Reddy, K.C.S. and
Raghavender, K.B.P. 2013. Physiological and haematological parameters of bitches affected with pyometra, Vetworld, 6(7): 409-412.

Jitpean, S., Holst, B.S., Emanuelson, U., Hoglund, O., Pettersson, A., AlnerydBull, C. and Hangman, R. 2014. Outcome of pyometrain female dogs and predictors of peritonitis and prolonged postoperative hospitalization in surgically treated cases, BMC Vet Res, 10:6.

Nath, K., Tiwari, S.K. and Kalim, O. 2009. Physiological and haematological changes in bitches with Pyometra, Indian Vet. J, 86: 734-736.

Prasad, V.D., Kumar, P.R. and Sreenu, M. 2017. Pyometra in Bitches: A Review of Literature. Research \& Reviews: Journal of Vet Sc and Tech, 6(2): 1220.

Reidun, H., Veronica, K., Jon, T. and Johan, H.J. 2007. Renal histomorphology in dogs with pyometra and control dogs, and long term clinical outcome with respect to signs of kidney disease, ActaVeterinariaScandinavica, 49(1): 13.

Shyma, V.H. and Vijayakumar, K. 2011. Haematological studies in dogs affected with Bacterial Dermatitis, Vet.Anim.Sci., 42: 20-22.

Singh, S., Dadhich, H. and Sharma, G.D. 2006. Haemato- biochemical studies in cystic endometrial hyperplasia pyometra complex in canine, Indian $\mathrm{J}$ Vet Pathol, 30: 46-48.

Smith, F.O. 2006. Canine pyometra. Theriogenol, 66(3): 610-612.

\section{How to cite this article:}

Maharathi. S. P., N. Dalai, S. Mohapatra, S. R. Mishra, A. P. K. Mahapatra, A. K. Kundu, I. Nath and Dash. S. 2020. Haemato-Biochemical Alterations in Pyometra Affected Bitch. Int.J.Curr.Microbiol.App.Sci. 9(06): 1242-1245. doi: https://doi.org/10.20546/ijcmas.2020.906.153 